\title{
Indigenous Institutions and Their Role in Disaster Risk Reduction and Resilience: Evidence from the 2009 Tsunami in American Samoa
}

\author{
Andrew Rumbach ${ }^{1}$ and Dolores Foley ${ }^{2}$
}

\begin{abstract}
Indigineity has emerged as an important area of focus for research and policy making on disaster risk reduction (DRR) and resilience. Most research on indigeneity and DRR centers on indigenous knowledge and its integration with western scientific understandings of hazards and risk. Through a detailed case study of the 2009 tsunami in American Samoa, we argue that indigenous institutions also play a critical role in disaster risk reduction and resilience. Based on original data from semistructured interviews, village planning meetings, and focus group discussions, we describe how the indigenous institutions of fa'a Samoa, or the culture of Samoa, operated in a time of crisis by: (1) structuring emergency decision making and authority; (2) assigning roles and responsibilities during crises; (3) building effective lines of communication between villages and outside actors; (4) providing a system of accountability for vulnerable people; and (5) acting as gatekeepers to villages and mobilizing social groups to act. We then suggest some ways that indigenous institutions could be better leveraged to help create more resilient communities.
\end{abstract}

Key Words: American Samoa; disaster management; disaster risk reduction; indigenous knowledge; institutions; resilience; tsunami

\section{INTRODUCTION: INDIGENEITY AND DISASTER RISK REDUCTION}

On September 29, 2009, three earthquakes occurred near simultaneously in the South Pacific Ocean (Beavan et al. 2010). Less than 12 minutes later, a tsunami struck the U.S. island territory of American Samoa. One survivor remembers the first wave as it came ashore:

\begin{abstract}
...after the shaking stopped...the water start[ed] moving out, receding. The water was going out and the whole reef was exposed... we start [ed] to hear the water coming in, and the water is coming fast, there is a roar in it - a real mean sound... spooky... as it comes in, once it hit the side of the road, the tallest coconut tree was probably 30 feet tall, and the water just went over it... and then when it was going out that's when you start hearing the roofing irons collapsing, homes collapsing and cars going with it...as it was going out it was pulling everything it touched...
\end{abstract}

Three tsunami waves swept through the territory, killing 34 people, injuring hundreds more, and causing tens of millions of dollars in damage to homes and infrastructure. It was the single worst disaster in American Samoa's history, and one of the costliest U.S. territorial disasters in recent memory. It was also the first tsunami to cause deaths on American soil in over 30 years.

We describe indigenous institutions in American Samoan villages and their role in disaster risk reduction (DRR) and resilience, drawing on a detailed case study of the 2009 tsunami and its aftermath. As described by the UN International Strategy for Disaster Reduction (UN-ISDR), disaster risk reduction is the:

...concept and practice of reducing disaster risks through
systematic efforts to analyse and manage the causal
factors of disasters, including through reduced exposure
to hazards, lessened vulnerability of people and property,
wise management of land and the environment, and
improved preparedness for adverse events. (http://www.
unisdr.org/we/inform/terminology)

${ }^{1}$ University of Colorado Denver, ${ }^{2}$ University of Hawaii, Manoa
We found that the indigenous institutions of fa'a Samoa, the culture of Samoa, played an important role in DRR, but could be better leveraged by planners and policy makers to reduce community vulnerabilities to environmental hazards and increase resilience. Disaster risk reduction is a concept and set of practices that apply to every phase of disasters and disaster management, including preparedness, response, recovery, mitigation, and adaptation (UN-ISDR 2009). Indigenous institutions in American Samoa play, or could play, an important role that across the spectrum of risk reducing activities.

Our study contributes to an emerging literature in disaster studies on the importance of indigenous knowledge and practices as components of DRR (Dekens 2007, Shaw et al. 2008, Mercer and Kelman 2010, Mercer et al. 2010). There has been a longstanding interest in indigenous knowledge in fields like agriculture, medicine, and rural development (Richards 1985, Slikkerveer et al. 1995). Mainstream disaster science and policy, however, has marginalized indigenous and traditional forms of knowledge and practice, especially in western industrialized countries like the United States (McAdoo et al. 2006, Shaw et al. 2008, Mercer and Kelman 2010). Beginning with the 2004 Indian Ocean tsunami, there has been a growing focus in disaster and development research on how indigenous knowledge might be merged with scientific knowledge to more effectively reduce risk, improve response and recovery, and adapt to long-term climatic change. Our study of the 2009 tsunami shows that indigenous institutions also play important roles in DRR. In fact, the level of indigenous knowledge about tsunamis in American Samoa at the time of the 2009 event was extremely low; most survivors we interviewed had little or no knowledge about tsunamis, their warning signs, or how to respond to tsunami events. Those that did have that knowledge gained it primarily through training by federal agencies and scientific organizations rather than through traditional knowledge sources. However, our case study points to a number of different areas in which the fa'a Samoa, i.e., the culture of American Samoa, and its attendant institutions helped to save lives and speed recovery. Although many studies have described 
the social structure and institutions of Samoa and the Pacific Islands, we analyzed those institutions in the context of crisis. There are examples to demonstrate that fa'a Samoa's potential for disaster risk reduction is not being fully realized; we argue that with relatively small investments or changes in disaster management policies, American Samoa would be better prepared and less vulnerable to future hazards.

Although there is an active debate in the social sciences about the definition of institution, we follow Hodgson (2007:2) who broadly defined them as "systems of established and prevalent social rules that structure social interactions." As Giddens (1984:31) notes, "institutions by definition are the more enduring features of social life" and include everything from marriage to governing bodies (quoted in Miller 2011). Gopalakrishnan and Okada (2007:356) defined institutions in the context of disaster management as a "wide spectrum of entities that have a direct or indirect bearing on disaster risk management and mitigation," including culture, tradition, and customs. Indigenous institutions are simply those that existed prior to colonial rule. Although they have not featured strongly in the DRR literature, indigenous institutions have been carefully examined in the context of planning, natural resources, and sustainable development. Ostrom et al. (1993), for example, argued that institutions are central in determining the success or failure of development efforts. Similarly in his case study of an earthquake in Ecuador, Dudley (1988) recognized that indigenous institutions are essential for sustainable disaster mitigation and urged international agencies to support them prior to disaster events.

Understanding indigenous knowledge and institutions and the roles they play is important to community-based or bottom-up disaster management policies and practice. Disaster management in the United States has traditionally been top-down and focused largely on the relief phase of the disaster cycle. As Pearce (2003:211) described it, U.S. disaster management has traditionally "been done for, not with, the community" (referencing Laughy 1991). In the past decade, and especially after Hurricane Katrina exposed serious flaws in the nation's disaster preparedness, the Federal Emergency Management Agency (FEMA) has shifted away from top-down thinking and toward a 'whole community' paradigm for policy and practice (FEMA 2011). This shift in approach, at least in theory, will bring U.S. disaster management policy more in line with the principles of disaster risk reduction, which has long argued that disasters are local, context-specific, and primarily economic, social, and political, rather than natural, in origin (Wisner et al. 2004). Indigenous knowledge and institutions are deeply embedded in communities that are often marginalized within larger states, and are often obscure or invisible to top-down policies and programs. Within an emergency management paradigm like the 'whole community,' whose principles include the desire to "engage and empower all parts of the community" and to "strengthen what works well in communities on a daily basis," understanding and leveraging indigenous institutions is a vital step toward community resilience (FEMA 2011:4-5).

\section{AMERICAN SAMOA AND THE 2009 EARTHQUAKE AND TSUNAMI}

American Samoa is located on a series of small islands and coral atolls in the South Pacific Ocean. It became a territory of the
United States after the Tripartite Convention in 1899, when the U.S. and Germany effectively divided control over the Samoan islands. American Samoa is among the most geographically isolated territories of the United States. Pago Pago, the capital, is more than 2500 miles southwest of Hawaii and 7000 miles west of Washington, D.C.

American Samoa has a population of more than 55,000 people, more than $95 \%$ of whom live on the island of Tutuila (http://www. census.gov/2010census/news/pdf/cb11 cn177_ia_as totalpop_2010map. pdf). The territory shares close historical and cultural ties with the Independent State of Samoa, formerly Western Samoa, which lies just 80 miles to the west. Although American Samoa technically falls under the legal authority of the Department of the Interior, it is effectively self-governing. American Samoans ratified their own constitution in 1960 and democratically elect a territorial government.

Small island states and territories like American Samoa are among the most at-risk places in the world, in part because of their physical geography, remoteness, and exposure to natural hazards (Pelling and Uitto 2001, Douglas 2006). American Samoa's physical geography is a key driver of disaster risk, particularly to tsunamis and other coastal hazards. Tutuila has been described as a volcanic island that rises "precipitously from the ocean, and feature[s] narrow coastal strips of relatively flat land and rugged, mountainous interiors" (Volk 1993:1). Twothirds of the island has a slope of $30 \%$ or more, leaving the vast majority of the interior land uninhabitable. As a result, a significant portion of the population lives in low-lying coastal areas, and much of the critical infrastructure, including the majority of schools, are located near the shoreline. The vulnerability of coastal populations will be further exposed by the effects of global climate change, especially rising sea level and increasing storm activity and intensity (Wisner et al. 2004, Bettencourt et al. 2006, IPCC 2012).

Though earthquakes, hurricanes, and landslides are quite common in the territory, tsunamis are relatively rare. Records are scarce, but the last tsunami to cause considerable damage was probably in the mid-20th century (see Pararas-Carayannis and Dong 1980 for an historical overview of tsunamis affecting the Samoan islands). Nearly every survivor we spoke to described the 2009 event as the first tsunami in American Samoan history. One interviewee, typical of all respondents, described their experience with tsunamis:

\section{...In the past we have a very strong earthquake but there was no tsunami. So that was the problem...it is the first time it ever happened to us over here. First time and hopefully it will be the last time.}

The tsunami was caused by a series of underwater earthquakes at the Tonga Trench, a fast moving subduction zone at the intersection of the Pacific and Australian plates, just 120 miles south of the territory (Fig. 1; Wright et al. 2000, USGS 2009, U. S. Army Corps of Engineers 2012).

After a brief period of intense ground shaking, the first tsunami wave reached American Samoa 8-12 minutes later. The period between the earthquake and the tsunami left very little time for warning: 


\begin{abstract}
We heard a real mean earthquake... but I don't know if this earthquake will ever stop, it getting stronger and stronger...first wave came, took our house, took my car... the next thing I know is there's another wave coming and its getting bigger. It was getting bigger, I tell you! ... when the wave hit me, I don't know what was up, down, up down, I was taking in a lot of water, I was worried I was going to die that morning. But God is so good, I made it. I put up my hand and like, 'oh thank God I'm still alive.'
\end{abstract}

Fig. 1. American Samoa and the larger region.

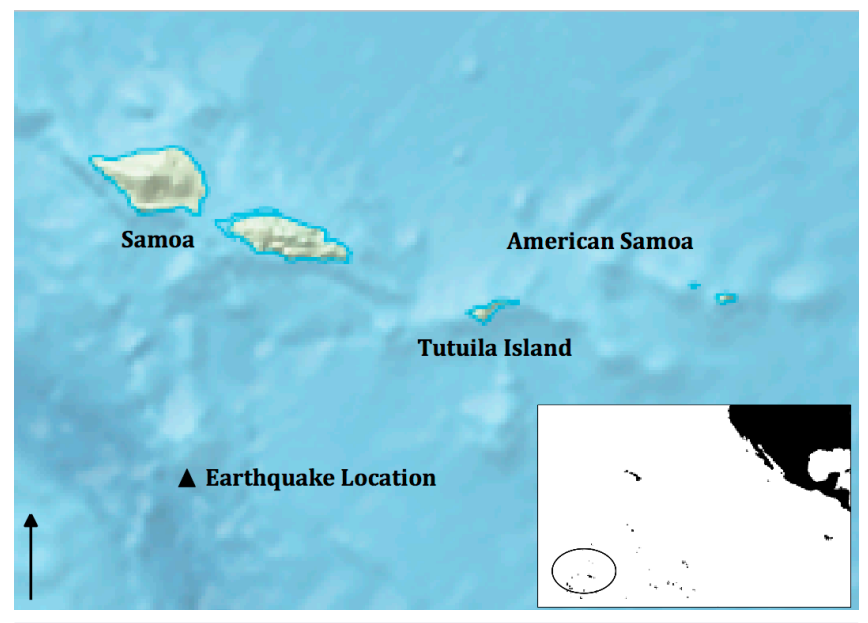

With the short time period between earthquake and tsunami, the size of the waves, challenging topography of the island, concentration of population and schools in low coastal areas, and the relative inexperience of the American Samoan people with tsunamis, it was quite remarkable that so few lives were lost. Part of the low mortality rate is attributable to timing; the earthquakes struck at 6:58 a.m. when most residents were awake and on their way to work or school. We argue that the indigenous institutions of fa'a Samoa also played a central role in local resilience to the tsunami, and in the successes and challenges in the ongoing recovery efforts.

\section{METHODS}

Our case study of the response and recovery to the 2009 tsunami is based on data gathered during six field visits to American Samoa, October 2010-December 2012, as part of a collaborative project between the department of Urban and Regional Planning at the University of Hawaii, National Oceanic and Atmospheric Administration (NOAA), and several coastal villages on Tutuila Island (Yin 2009). This larger project aims to improve the disaster resilience of American Samoan villages through communitybased planning and education. As a component of the larger project, we facilitated a series of public meetings and focus group discussions with residents of the Leone and Pago Pago villages, centering on the tsunami, local recovery, and needs and priorities for disaster risk reduction (Mercer et al. 2008). We also interviewed 28 survivors, village 'matai,' i.e., chiefs, members of village social organizations, territorial officials, representatives from FEMA, and other federal agencies. These semistructured interviews centered on questions about the tsunami, the recovery process, and about reducing the risk to future hazards. A list of interviewees by age, gender, occupational category, and interview date is available from the authors upon request. We conducted interviews in English, or with the help of a translator, in Samoan, or in a mixture of English and Samoan.

\section{FA'A SAMOA, THE SAMOAN WAY}

Life in American Samoa is largely guided by fa'a Samoa, the Samoan Way, an umbrella term that encompasses many of the indigenous institutions that govern the rights, responsibilities, and behaviors of the territory's citizens. American Samoa is unique among U.S. territories in that its indigenous institutions were recognized from the outset of colonial control and codified into the territorial deeds of cession in 1900 and 1904, and further protected in the territorial constitution (Leibowitz 1989). American Samoa elects a territorial government including a governor, legislature, and judiciary. At the same time a system of indigenous institutions operate within villages, nearly identical to those in the independent nation of Samoa (Daly et al. 2010). Although the territorial government is similar to and modeled after elected governments in U.S. states, the traditional governance structures in villages work in parallel to, rather than beneath, territorial authority. As one Samoan colleague explained "we [those of us living in states like Hawaii] assume a paradigm of county, state, federal government [indicating a hierarchy]...but this can stop right at the village boundary" (T. Avegalio, personal communication)

American Samoa is a collection of village communities ranging in size from hundreds to several thousands of people. Prior to U. S. and European influence, there was no higher government, and villages were largely self-sufficient and autonomous (Leibowitz 1989). Although a small part of the population does live outside of village culture, most American Samoans identify themselves as part of a village community.

The term 'fa'a Samoa' describes a range of different institutions that are fundamental to life in villages and across the territory. Fa'a Samoa is a complex and dynamic cultural concept, far beyond our scope to adequately describe (Freeman 1986, Volke 1993, Huffer and So'o 2005; Ala'ilima and Ala'ilima, unpublished manuscript). We focused on five institutions in fa'a Samoa that emerged during our study as especially relevant to DRR: (1) the 'aiga,' or extended family; (2) the 'matai,' or chiefs; (3) the 'fono, 'or village council; (4) the 'aumaga' and 'aualuma,' organizations of young men and women in each village; and (5) the 'pulenu'u, ' or village mayors.

Within each village, the basic unit of organization is the extended family or aiga. Aiga is a broader concept than the traditional American family; it includes biological relatives like parents and children, but also the extended household, i.e., brothers, sisters, nieces, nephews, cousins, etc., relatives by marriage, and adopted members. An aiga may include dozens or even hundreds of individuals who live in smaller household units. Aiga may live under the same roof or in close proximity to one another, but membership and obligations extend across spatial boundaries and include family members living in other communities, in American Samoa, or elsewhere. 
A matai, or chief, selected by the extended family, heads each aiga. Matai titles are granted by extended families to men or sometimes women and are usually held for life or into old age. The matai is directly responsible for the well-being of his or her aiga and makes decisions about the allocation of collective resources like the use of customary land owned by the extended family. The matai system is the predominant socioeconomic, political, and judicial institution of governance in Samoan families and villages. The matai are the decision-making authorities and, though they govern with the input of their family members, are ultimately responsible for guiding their aiga and the village.

A fono, or village council, governs each village (Table 1). The fono comprises the matai from each of the extended families in the village. The fono makes decisions that are of common interest to families living in the village, adjudicates disputes between families, metes out punishment to individuals who commit crimes within the village, and organizes or performs certain ceremonies or events for the collective good (Ala'ilima and Ala'ilima, unpublished manuscript). In extreme cases, the fono may banish individuals or families from the village, effectively dispossessing them of their land and associated rights (Stover 1999). Based on a village hierarchy of clan titles, the highest ranking matai in the fono, the paramount chief or ali'i, is the ultimate decision maker: "[he] listens until he thinks he can state a compromise which, given his great influence, will result in general agreement" (Stover 1999:10).

Table 1. Indigenous institutions in fa'a Samoa.

\begin{tabular}{|c|c|}
\hline Institution & Description \\
\hline Fono & $\begin{array}{l}\text { Village council; made up of matai from each of the } \\
\text { aigas. }\end{array}$ \\
\hline Matai & Chiefs, or holders of chiefly titles. \\
\hline Aiga & Extended families. \\
\hline Pulenu'u & $\begin{array}{l}\text { Village mayor; selected by the fono and appointed by } \\
\text { the territorial governor. }\end{array}$ \\
\hline Aumaga & Organization of untitled men. \\
\hline Aualuma & Organization of women; women's group. \\
\hline
\end{tabular}

There are several other groups that fall under the authority of the matai and who have responsibilities and authority in American Samoan villages. Two important groups are the aumaga and aualuma. The aumaga are a group of untitled men, often young and unmarried, who work under the direction of village matai. Traditionally the aumaga were the laborers and warriors in the village, the "hands and feet" to the "brains" of the matai (Leibowitz 1989). Today the aumaga play a variety of roles in village security, like patrolling the village during prayer hours, policing after nightfall, and providing ceremonial protection for the regular meeting of the village fono. Likewise, the aualuma is an association of women in each village. Like the aumaga, the aualuma play a central role in traditional village life, especially with regard to service to the matai and with hospitality for visitors. In contemporary Samoan life, the aualuma often take the lead on organizing community projects, social events, and other public interest activities.

The pulenu'u, or village mayor, provides an important link between the territorial government and the village. Though it was originally a construct of the German colonial authority in
Western Samoa, the institution of the pulenu'u has slowly been incorporated into fa'a Samoa. The pulenu'u is often described as the village mayor, but their actual authority can be more limited because decision-making power is vested primarily in the matai and the village fono (Riddle 2006). The pulenu'u is the only position within the village governance structure that is salaried by the territorial government and is often selected from matai or other persons of stature in the village. The pulenu'u plays an important role as the go-between for the village and outside groups, including the territorial government, federal agencies, and nongovernmental organizations. They are the "eyes and ears" of the territorial government but chosen by the village fono, giving the pulenu'u a unique position in the village leadership, having both insider and outsider status. Protocol requires that outside organizations and agencies wishing to work inside villages must first contact the office of Samoan Affairs, which relies on the pulenu'u to then make contact with their village fono. In a hierarchical system like fa'a Samoa, the pulenu'u is important because the institution carries with it a certain amount of respect and authority, which is then used to broker conversations between villages and outsiders who do not enjoy any status within the village system itself.

\section{FA'A SAMOA IN TIMES OF CRISIS: THE 2009 TSUNAMI}

Many studies have described the social organization of Samoan villages and the institutions of fa'a Samoa (Hirsh 1958, Huffer and So'o 2005, Corrin 2008; Ala'ilima and Ala'ilima, unpublished manuscript), but few have documented the roles these institutions play in the context of environmental crises. The 2009 tsunami and its immediate aftermath illuminated the central importance of indigenous institutions in shaping local response to disaster. We described the roles indigenous institutions played during and after the American Samoa tsunami. Our list is far from complete; we intended it is a starting point that that will be added to by additional research and case studies.

The first function of indigenous institutions is that they structure emergency decision making and authority. The hierarchy of leadership within individual aiga and in village communities is practiced and maintained on an everyday basis and is left intact even in the event of a catastrophic disaster like the 2009 tsunami. Naturally, after the tsunami, villagers look to the village leadership to guide response activities. As one matai described the scene in Leone village immediately following the tsunami:
[The matai] went out and started calling everybody, the young men [aumaga], and right there [pointing to an empty concrete slab where a traditional house once stood], we start putting our little village center on that cement and all the chiefs came and they start organizing everything.

Because the hierarchy of leadership is established in each village community and operates independently of the territorial or federal government, it is present even in the event of a disaster that overwhelms the capacity of outside agencies to respond quickly or comprehensively, particularly important in island communities like American Samoa that are geographically isolated and difficult to reach.

Indigenous institutions also assign roles and responsibilities during crises. As the "hands and feet" of the village, the aumaga 
were dispatched immediately to rescue individuals from the tsunami waves, conduct search and rescue operations, and clear debris from the roads and other critical infrastructure. Time and again in our interviews, the aumaga received praise for their heroics during the tsunami and are credited with saving many lives. The aumaga were crucially important for emergency response because with such widespread devastation across the island, they were the de facto first responders. Based in each village, they were capable of responding to events locally and without having to be dispatched from larger population centers. The aumaga also had knowledge about the village itself that is lost on outsiders but crucial for emergency response, as one territorial emergency management official described:

They know what is going on in their village and [outside agencies and organizations ] depend on it. For the basic reason that homes do not have numbers...do not have driveways. Certain homes are on a path, you cross streams...so the village people themselves, the aumaga, the people of that community know best how to get there and account for members.

The local presence of the aumaga in each village is also beneficial on an island in which transportation infrastructure lacks redundancy. In 2009 the tsunami destroyed a bridge in the village of Leone, the only overland road link between villages on the western side of Tutuila and the rest of the island. Thirteen villages were effectively cut off from emergency vehicles and services, which are dispatched from the larger villages of Pago Pago and Tafuna. The director of emergency services for the territory remembers that "...once that bridge went down, the vehicles stopped...everything stopped." There was significant damage on the western side of the island, where the tsunami wave first struck and where wave run-up heights reached more than 35 feet. Emergency responders were forced to cross the stream on foot to try and reach the western villages, across rugged terrain and many miles. In the meantime, the matai had organized the aumaga to rescue tsunami victims and perform other emergency response duties.

The aualuma is another traditional social group that played a vital role in the post-tsunami period. Although they have not received as much attention and praise in the press, the aualuma also played a critical role in hours and days after the tsunami. Many of the affected villages looked to the aualuma to organize and manage a range of emergency activities. The director of Emergency Medical Services explained:

...within Samoan society you normally hear about the
men...the aumaga...what the men do and so forth. You
will find that on the other side...the women play a very
important role and the men's role cannot be done unless
it is supported by what the women do...the men are going
to be jumping in the water...climbing the debris. The
women will be taking their victims... and are going to
apply first aid and take care of them until help arrives...
they need to be fed. They need water. The kids need to be
looked after. You got elderly people...the [aualuma]
helped a lot with this.

The next function of indigenous institutions is that they build effective lines of communication within villages and between villages and outside organizations and agencies. One of the great success stories for disaster resilience that emerged after the 2009 tsunami was the performance of the pulenu'u in sounding village alarms to warn of an impending tsunami. Just weeks prior to the event, the pulenu'u attended a training on how to recognize the warning signs for a potential tsunami event and the proper procedures to follow to evacuate their respective villages. Amanave is exemplary of the impact of this training. Amanave is a small village of 300 people on the far western side of Tutuila Island and was one of the earliest and hardest hit villages. Located at sea level, the tsunami waves destroyed or caused major damage to every building in the village save one, and yet the entire population survived without any major injuries. The survivors largely credited the actions of the village pulenu'u, who "evacuated the entire village as soon as he arrived minutes after the earthquake, and he didn't stop calling out to the village while the tsunami was approaching land. The pulenu'u's children literally had to force him to safety" (PTRTF 2009). As described earlier, the pulenu'u is a unique institution within fa'a Samoa because it is recognized and has responsibilities in both the village and the territorial government. In the case of the 2009 tsunami, the pulenu'u served as a vital communication link between federal and territorial agencies issuing tsunami warnings and villagers who were at risk. Their role and authority to issue warnings was established in the village and were thus effective at mobilizing villagers to evacuate to high ground, even if they themselves were not knowledgeable about the connection between earthquakes and tsunamis. Because the institution is based in the village and the pulenu'u is a village resident, there is also an accountability structure in place in case they do not perform their duties correctly. It is probably no coincidence that lives were lost in the two villages in which the pulenu' $u$ fled rather than signaling the alarm (PTRTF 2009). In both cases, the pulenu'u was fired from his position and has brought shame to himself and his family, described by one matai as "the worst punishment in Samoan culture" that will "stay with them for years."

An institution like the aiga provides accountability for vulnerable groups who are often socially isolated and fall through the cracks during crisis events (Klinenberg 2003). Most people living in American Samoan villages belong to an aiga or are under the care of one as a guest. During several of our workshops and discussions about disaster vulnerability, we asked participants to think about vulnerable populations and the best way to account for them during an emergency. In each case, the participants pushed back against the basic concept. They argued that the responsibility for vulnerable groups would automatically and naturally fall under the responsibilities of the aiga and its contingent households. During a follow up interview, one matai explained that Samoans are "all about family" and that "in an emergency situation, every person will be taken into account." $\mathrm{He}$ explained that even if there were a vulnerable person living alone, the neighbors would know about that person and take responsibility for them in the event of a crisis. Another interviewee added "it would be a no-brainer that everybody would take care of each other." The cultural norm of the aiga caring for its members has been documented in other contexts as well. For example, Ta'ele (2001:1) writes that the concept of elderly care or nursing homes is a "foreign concept which contradicts the traditional Samoan home care practices" and that "any Samoan 
will tell you that Samoans take care of their own elderly and disabled members of their family" (Ta'ele 2001:7).

The centrality of institutions like the aiga raises additional concerns about nonindigenous groups in places like American Samoa. Studies on indigenous knowledge in DRR stress the need to plan differently for indigenous and nonindigenous populations because of their differing understandings of environmental hazards (McAdoo et al. 2009). Similarly, more data are needed to understand how nonindigenous groups manage disaster risk, given that they may not benefit from the capacities and resources that village institutions lend.

Beyond response, indigenous institutions also played key roles in village recovery and in planning for future tsunamis and other coastal hazards. Crucial for outsiders to understand is that the fono and its matai are the gatekeepers to villages and extended families and have complete authority and control over village land and resources. As institutions, they lend access to villages and give credibility to outside agencies, organizations, and projects. The matai and fono can ultimately determine whether the outreach efforts are successful or not. One of our interviewees from the territorial government warned us that "...if the matai feel that they are not respected, outside agencies and groups will quickly find themselves without participation or support." The decisions that the matai make on behalf of their families and villages will be followed without question, and so there are very few alternatives for local engagement than to go through the established protocols and hierarchies. As one Samoan project member observed at a planning meeting with village chiefs: "You could have one thousand people from the village here, but if they [the matai] are not present, it would be a waste of time."

If such efforts receive the support and blessing of the matai and fono, they will then have the implicit support of the village as the cultural hierarchy dictates. Another key role of indigenous institutions, then, is that they socially mobilize families and groups to act. Social mobilization is the process of engaging with a wide range of actors to achieve a common goal (see UNICEF http://www.unicef.org/cbsc/index 42347.html). After the tsunami, several village fonos announced their decision to prioritize resilience in their recovery process, which opened the door for the delivery of planning, education, and training resources that would have otherwise been unable to reach the community. With the support of the matai, planning meetings in these villages were well attended and resulted in substantive collaborations between outside agencies, organizations, and village institutions. A full accounting of this process of community engagement is beyond our scope, but it is important to note that the crucial variable for ensuring social mobilization for planning efforts was the advice, consent, and support of the family and village leadership.

\section{CONCLUSION: LEVERAGING INDIGENOUS INSTITUTIONS FOR COMMUNITY RESILIENCE}

Why do these indigenous institutions of fa'a Samoa 'work' during times of crisis? There are several likely explanations. Perhaps most important is that the institutions are an integral part of daily life, practiced, tested, and reinforced across a diverse range of social interactions and in a variety of contexts, unlike many institutions or tools that are specific to disasters that are implemented every few months, years, or decades. The institutions of fa'a Samoa have proven remarkably resilient and carried the culture through innumerable social and political crises. It is only natural that in times of disaster, victims would reflexively rely on those institutions to guide their actions. This leads to a second explanation, that indigenous institutions like those of fa'a Samoa engender a great deal of social capital, a critical component for successful disaster response and recovery (Nakagawa and Shaw 2004, Dynes 2006, Aldrich 2012). Putnam (1995:67) described social capital as the "features of social organization such as networks, norms, and social trust that facilitate coordination and cooperation for mutual benefit." Indigenous institutions effectively reduce transaction costs between participating individuals and groups, critical in postdisaster scenarios in which speed is paramount.

The case of fa'a Samoa shows how indigenous institutions increase local capacity for DRR (Wisner et al. 2012). It also points to some of the unrealized potential bound up in such systems. The fa'a Samoa, in and of itself, is not a panacea for disaster. When combined with the knowledge and resources available at the territorial and national scale, however, such institutions could improve disaster response and resilience in a number of important ways (Table 2).

We already described the pulenu'u and the training they received to recognize the warning signs of tsunami and to sound the villagewide alarm. The training of the pulenu'u was exemplary but the vast majority of DRR resources delivered to American Samoa go to territorial agencies and bureaucrats rather than villages and communities. The aumaga are an example of an indigenous social organization with untapped capacity. One territorial official reflected on the day of the tsunami and what it revealed:

I see all these aumaga running around, just looking for
anybody to help. That's when I realized with all the
training I had, first responder and that stuff. You know
we [territorial officials] were all trained in that stuff.
This was the first day I realized it was the aumaga...they
were the true heroes. (P. Gurr, personal communication)

The director of emergency services confirmed that the aumaga lacked some of the basic knowledge necessary for effective response and medical triage. "For all the bravery exhibited by the aumaga," he lamented, "most of them did not know CPR" (G. F. Avegalio, personal communication). The CPR example is representative of a broader lesson that the aumaga, in general, lack some of basic skills that would make them more effective first responders, a role the institution naturally plays within the social organization of the village. The aumaga will reliably exist with or without external funding or ongoing support, and so a modest investment of resources to train the aumaga in a program like Community Emergency Response Teams (CERT) would leverage the institution for more effective and efficient DRR. The same is true for the aualuma, who could be targeted for training on mass feeding, emergency elderly care, psychological triage, and other disaster response capacities that dovetail with their responsibilities to their aiga and villages. Aualuma groups might also be the most appropriate organizations to train to house and maintain emergency supply kits for villages, for example, so that such resources are not concentrated in any one place and are available to disaster affected communities even in the event they are cut off from transportation networks. 
Table 2. Indigenous institutions, their role in the 2009 tsunami, and opportunities for disaster risk reduction (DRR).

\begin{tabular}{|c|c|c|}
\hline Institution & Role in 2009 Tsunami & Opportunities for DRR \\
\hline Fono & $\begin{array}{l}\text { Coordinated recovery efforts; acted as gatekeeper to outside } \\
\text { organizations and agencies wanting to work in villages; in } \\
\text { villages like Leone, prioritized long-term disaster resilience in } \\
\text { the recovery process. }\end{array}$ & $\begin{array}{l}\text { Establish relationships predisaster to build trust and establish } \\
\text { common goals; work together to prioritize disaster resilience in } \\
\text { village decisions; grant fono access to DRR resources typically } \\
\text { reserved for nonprofit organizations and government agencies, } \\
\text { with appropriate oversight. }\end{array}$ \\
\hline Matai & $\begin{array}{l}\text { Coordinated emergency actions; mobilized social groups; } \\
\text { worked collectively as members of village fono to prioritize } \\
\text { resilience during recovery. }\end{array}$ & $\begin{array}{l}\text { Follow traditional protocols to build relationships and mutual } \\
\text { respect predisaster and to socially mobilize village for DRR } \\
\text { training and planning. }\end{array}$ \\
\hline Aiga & $\begin{array}{l}\text { Identified vulnerable individuals; acted as mechanism for aid } \\
\text { delivery; provided internal accountability for well-being of } \\
\text { members. }\end{array}$ & $\begin{array}{l}\text { Make focal point for emergency preparedness: make plans for } \\
\text { members with special needs; establish evacuation points and } \\
\text { household evacuation plans. }\end{array}$ \\
\hline Pulenu'u & $\begin{array}{l}\text { Received tsunami training and sounded alarm; brokered } \\
\text { contact and maintained lines of communication between } \\
\text { villages and territorial/federal agencies during response and } \\
\text { recovery. }\end{array}$ & $\begin{array}{l}\text { Build on success of earlier tsunami awareness by making the } \\
\text { pulenu'u a DRR liaison between territorial/federal government } \\
\text { and village communities. }\end{array}$ \\
\hline Aumaga & $\begin{array}{l}\text { Performed search and rescue operations; acted as first } \\
\text { responders; removed debris and cleared roads. }\end{array}$ & $\begin{array}{l}\text { Provide training in disaster response and first aid (CERT or } \\
\text { equivalent); provide basic rescue equipment and tools. }\end{array}$ \\
\hline Aualuma & $\begin{array}{l}\text { Provided mass care, feeding, and triage services until outside } \\
\text { agencies and organizations arrived; in Leone village, organized } \\
\text { construction of a healing garden to memorialize the tsunami } \\
\text { and aid in emotional and psychological recovery. }\end{array}$ & $\begin{array}{l}\text { Train in mass feeding, care, and first aid; provide training for } \\
\text { procurement and maintenance of emergency supplies for village. }\end{array}$ \\
\hline
\end{tabular}

One village leader stressed that such trainings would not only strengthen the capacity of village organizations for DRR but the organizations themselves. Centralized systems of emergency response, he argued, can perversely weaken these indigenous institutions by making villagers more dependent on outsiders for functions they have the capacity to perform themselves:

...the village people themselves, the village organization,
village structure, village politics has their own system for
taking care of the village people. They pretty much have
a system for evacuation, they have a system for moving,
they have a system for taking care of the elderly and the
children... the aumaga, the people that actually rescued
themselves and rescued their neighbors...those are the
groups that need training... [the villagers] got the inner
skills to do it. What we want to do is work with them to
move them up to the next level.

The leader's comments also highlight a common fear among older American Samoans, that younger generations are losing touch with some of the traditions and protocols central to fa'a Samoa. The institutions have proven remarkably durable over time because they have adapted to changing political, economic, and social conditions. For example, family networks are more spatially diffuse than in the past because of increased off-island migration. Technologies like cellular phones and the internet allow the matai to carry out their obligations even across large distances, maintaining the central importance of the aiga even in the Samoan diaspora. The continued resilience of American Samoan institutions hinges partly on their ability to continually adapt to the complex challenges of contemporary life. Village leaders see DRR as one avenue to reinforce the relevance of institutions locally and to adapt the roles and responsibilities of organizations like the aumaga and aualuma to address an important village issue.
These are just a few examples of areas in which building local capacity through the institutions of fa'a Samoa could contribute significantly to DRR and resilience. The inherent potential of indigenous institutions needs be recognized and nurtured in predisaster plans and policies, however, rather than in ex post analyses. The FEMA's recent turn back toward community-based disaster management is an opportunity to craft policies and plans that are more flexible to diverse local conditions, needs, and priorities. It is also, hopefully, an opportunity for indigenous communities to influence disaster management policy and to access the resources they need to strengthen local capacity. Supporting indigenous institutions through disaster management policies and programs can leverage existing networks with high levels of social capital, while simultaneously strengthening those institutions and making them relevant to contemporary challenges; it is a win-win scenario. Building relationships with indigenous communities requires a significant investment of time and resources, however. In American Samoa, following traditional protocols to work with matai, fonos, pulenu'u, and other village institutions can be a laborious and difficult process. Based on evidence from the 2009 tsunami, however, the payoff would be significant.

Our study of the 2009 tsunami raises some important questions for future research. Most important, more study is needed to expand and sharpen our understanding of the roles that indigenous institutions play in DRR in other contexts, in the Pacific Islands or elsewhere. Our knowledge of how territorial status has an impact on disaster risk is also fairly limited. The literature on small island vulnerability and resilience centers on developing states and tends to exclude territories and protectorates from its scope of analysis (Lewis 1990, Pelling and Uitto 2001, Barnett and Adger 2003, Kelman 2010), with some notable exceptions (Patton and Johnston 2001, Kelman et al. 2006). American Samoa's territorial status lends it access to a 
wealth of resources from the U.S. federal government, but constrains its ability to shape a disaster management policy that is reflective of indigenous traditions, knowledge, and ways of life (Daly et al. 2010). More research is needed to understand how indigenous ways of doing and knowing are supported in federal emergency management policies, which are structured largely according to the needs and priorities of states. This is important not just for DRR in American Samoa, but in other U.S. indigenous contexts like Alaskan native villages, Native American reservations, and other island territories.

Responses to this article can be read online at: http://www.ecologyandsociety.org/issues/responses. php/6189

\section{Acknowledgments:}

We would like to thank Makena Coffman, Ashok Das, Priyam Das, Ilan Kelman, Karl Kim, Daniele Spirandelli, Karen Umemoto, and two anonymous reviewers for their comments on earlier drafts of this paper. The research for this paper was carried out with support from NOAA (grant \#NA10N0S4730201) and the National Disaster Preparedness Training Center (NDPTC).

\section{LITERATURE CITED}

Aldrich, D. P. 2012. Building resilience: social capital in postdisaster recovery. University of Chicago Press, Chicago, Illinois, USA.

Barnett, J., and N. W. Adger. 2003. Climate dangers and atoll countries. Climatic Change 61:321-337. http://dx.doi.org/10.1023/ B:CLIM.0000004559.08755.88

Beavan, J., X. Wang, C. Holden, K. Wilson, W. Power, G. Prasetya, M. Bevis, and R. Kautoke. 2010. Near-simultaneous great earthquakes at Tongan megathrust and outer rise in September 2009. Nature 466:959-963. http://dx.doi.org/10.1038/nature09292

Bettencourt, S., R. Croad, P. Freeman, J. Hay, R. Jones, P. King, P. Lal, A. Mearns, G. Miller, I. Pswarayi-Riddihough, A. Simpson, N. Teuatabo, U. Trotz, and M. Van Aalst. 2006. Not if but when: adapting to natural hazards in the Pacific Islands region. World Bank, Washington, D.C., USA. [online] URL: http:// siteresources.worldbank.org/INTPACIFICISLANDS/Resources/ Natural-Hazards-report.pdf

Corrin, J. 2008. Land, law reform and the faa-Samoa. LawAsia Journal 2008:31-46.

Daly, M., N. Poutasi, F. Nelson, and J. Kohlhase. 2010. Reducing the climate vulnerability of coastal communities in Samoa. Journal of International Development 22:265-281. http://dx.doi. org/10.1002/jid.1678

Dekens, J. 2007. Local knowledge for disaster preparedness: a literature review. International Centre for Integrated Mountain Development (ICIMOD), Kathmandu, Nepal. [online] URL: http://www.preventionweb.net/english/professional/publications/ v.php?id=2693
Douglas, C. H. 2006. Small island states and territories: sustainable development issues and strategies - challenges for changing islands in a changing world. Sustainable Development 14(2):75-80. http://dx.doi.org/10.1002/sd.297

Dudley, E. 1988. Disaster mitigation: strong houses or strong institutions? Disasters 12(2):111-121. http://dx.doi.org/10.1111/ j.1467-7717.1988.tb00657.x

Dynes, R. R. 2006. Social capital dealing with community emergencies. Homeland Security Affairs 2(2):1-26. [online] URL: "http://www.hsaj.org/?article=2.2.5

Federal Emergency Management Agency (FEMA). 2011. A whole community approach to emergency management: principles, themes, and pathways for action. Federal Emergency Management Agency, Washington, D.C., USA. [online] URL: http://www. fema.gov/media-library-data/20130726-1813-25045-0649/ whole community dec2011 2 .pdf

Freeman, D. 1986. Margaret Mead and Samoa: the making and unmaking of an anthropological myth. Penguin, New York, New York, USA.

Giddens, A. 1984. The constitution of society. University of California Press, Berkeley, California, USA.

Gopalakrishnan, C., and N. Okada. 2007. Designing new institutions for implementing integrated disaster risk management: key elements and future directions. Disasters 31 (4):353-372. http://dx.doi.org/10.1111/j.1467-7717.2007.01013.x

Hirsh, S. 1958. The social organization of an urban village in Samoa. Journal of the Polynesian Society 67(3):266-303.[online] URL: http://www.jps.auckland.ac.nz/document/?wid=2935

Hodgson, G. M. 2006. What are institutions? Journal of Economic Issues 40(1). [online] URL: http://checchi.economia.unimi.it/ corsi/whatareinstitutions.pdf

Huffer, E., and A. So'o. 2005. Beyond governance in Samoa: understanding Samoan political thought. Contemporary Pacific 17(2):311-333. http://dx.doi.org/10.1353/cp.2005.0054

Intergovernmental Panel on Climate Change (IPCC). 2012. Managing the risks of extreme events and disasters to advance climate change adaptation. Cambridge University Press, Cambridge, UK. [online] URL: http://ipcc-wg2.gov/SREX/ images/uploads/SREX-All_FINAL.pdf

Kelman, I. 2010. Hearing local voices from small island developing states for climate change. Local Environment 15 (7):605-619. http://dx.doi.org/10.1080/13549839.2010.498812

Kelman, I., M. Davies, T. Mitchell, I. Orr, and B. Conrich. 2006. Island disaster para-diplomacy in the commonwealth. Round Table 95(386):561-574. http://dx.doi.org/10.1080/00358530600929925

Klinenberg, E. 2003. Heat wave: a social autopsy of disaster in Chicago. University of Chicago Press, Chicago, Illinois, USA. http://dx.doi.org/10.7208/chicago/9780226026718.001.0001

Laughy, L. 1991. A planner's handbook for emergency preparedness. Centre for Human Settlements, University of British Columbia, Vancouver, British Columbia, Canada. 
Leibowitz, A. H. 1989. Defining status: a comprehensive analysis of United States territorial relations. Martinus Nijhoff, Boston, Massachusetts, USA.

Lewis, J. 1990. The vulnerability of small island states to sea-level rise: the need for holistic strategies. Disasters 14(3):241-249. http:// dx.doi.org/10.1111/j.1467-7717.1990.tb01066.x

McAdoo, B. G., L. Dengler, G. Prasetya, and V. Titov. 2006. How an oral history saved thousands on Indonesia's Simeulue Island during the December 2004 and March 2005 tsunamis. Earthquake Spectra 22:S661. http://dx.doi.org/10.1193/1.2204966

McAdoo, B. G., A. Moore, and J. Baumwoll. 2009. Indigenous knowledge and the near field population response during the 2007 Solomon Islands tsunami. Natural Hazards 48(1):73-82. http://dx. doi.org/10.1007/s11069-008-9249-z

Mercer, J., and I. Kelman. 2010. Living alongside a volcano in Baliau, Papua New Guinea. Disaster Prevention and Management 19(4):412-422. http://dx.doi.org/10.1108/09653561011070349

Mercer, J., I. Kelman, K. Lloyd, and S. Suchet-Pearson. 2008. Reflections on use of participatory research for disaster risk reduction. Area 40(2):172-183. http://dx.doi.org/10.1111/ j.1475-4762.2008.00797.x

Mercer, J., I. Kelman, L. Taranis, and S. Suchet-Pearson. 2010. Framework for integrating indigenous and scientific knowledge for disaster risk reduction. Disasters 34(1):214-239. http://dx.doi. org/10.1111/j.1467-7717.2009.01126.X

Miller, S. 2011. Social Institutions. The Stanford encyclopedia of philosophy (Fall 2012 Edition). Edward N. Zalta (ed.). [online] URL: http://plato.stanford.edu/archives/fall2012/entries/social-institutions

Nakagawa, Y., and R. Shaw. 2004. Social capital: a missing link to disaster recovery. International Journal of Mass Emergencies and Disasters 22(1):5-34. [online] URL: http://ijmed.org/articles/235/ download/

Ostrom, E., L. Schroeder, and S. Wynne. 1993. Institutional incentives and sustainable development: infrastructure policies in perspective. Westview, New York, New York, USA.

Pararas-Carayannis, G., and B. Dong. 1980. June. Catalog of tsunamis in the Samoan Islands. International Tsunami Information Center. [online] URL: http://www.drgeorgepc.com/ TsunamiSamoaIslandsCatalog.pdf

Patton, D., and D. Johnston. 2001. Disasters and communities: vulnerability, resilience and preparedness. Disaster Prevention and Management 10(4):270-277. http://dx.doi.org/10.1108/EUM0000000005930

Pearce, L. 2003. Disaster management and community planning, and public participation: how to achieve sustainable hazard mitigation. Natural Hazards 28:211-228. http://dx.doi.org/10.1023/ A:1022917721797

Pelling, M., and J. L. Uitto. 2001. Small island developing states: natural disaster vulnerability and global change. Environmental Hazards 3(2):49-62. http://dx.doi.org/10.1016/S1464-2867(01) $\underline{00018-3}$

Post-Tsunami Review Task Force (PTRTF). 2009. Post-Tsunami Review Task Force Report. Government of American Samoa, Pago Pago, American Samoa, USA.
Putnam, R. 1995. Bowling alone: America's declining social capital Journal of Democracy 6(1):65-78. http://dx.doi.org/10.1145/358916.361990

Richards, P. 1985. Indigenous agricultural revolution: ecology and food crops in West Africa. Harper Collins, New York, New York, USA.

Riddle, K. 2006. The Pulenu'u in Samoa: the transformation of an office. Thesis. University of Hawaii, Manoa, Hawaii, USA. [online] URL: http://scholarspace.manoa.hawaii.edu/bitstream/handle/10125/21121/ Riddle 2006 r.pdf?sequence $=1$

Shaw, R., N. Uy, and J. Baumwoll, editors. 2008. Indigenous knowledge for disaster risk reduction: good practices and lessons learned from experiences in the Asia-Pacific region. United Nations Office for Disaster Risk Reduction (UNISDR), Bangkok, Thailand.

Slikkerveer, L. J., D. M. Warren, and D. Brokensha, editors. 1995. The cultural dimensions of development: indigenous knowledge systems. Intermediate Technology, London, UK.

Stover, M. 1999. Individual land tenure in American Samoa. Contemporary Pacific 11(1):69-104. [online] URL: http:// scholarspace.manoa.hawaii.edu/bitstream/handle/10125/13258/ v11n1-69-104.pdf?sequence $=1$

Ta'ele, M. T. 2001. The attitudes of Samoans toward nursing home care in American Samoa. Dissertation. Golden Gate University, San Francisco, California, USA.

United Nations International Strategy for Disaster Reduction (UN-ISDR). 2009. UN-ISDR terminology on disaster risk reduction. UN-ISDR, Geneva, Switzerland. [online] URL: http:// www.unisdr.org/we/inform/terminology

United States Army Corps of Engineers, Honolulu District. 2012. American Samoa tsunami study: final report. United States Army Corps of Engineers, Honolulu District, Honolulu, Hawaii, USA. [online] URL: http://americansamoarenewal.org/sites/default/ files/resource documents/ASTS Final Report-031312.pdf

U.S. Geological Survey (USGS). 2009. Magnitude 8.1: Samoa Islands region. U.S. Geological Survey, Reston, Virginia, USA. [online] URL: http://earthquake.usgs.gov/earthquakes/eqinthenews/2009/ us2009mdbi/

Volke, R. D. 1993. American Samoa: introduction. Pages 1-15 in D. A. Scott, editor. A directory of wetlands in Oceania. Wetlands International, Wageningen, the Netherlands.

Wisner, B., P. Blaikie, T. Cannon, and I. Davis. 2004. At risk: natural hazards, people's vulnerability and disasters. Routledge, New York, New York, USA.

Wisner, B., J. C. Gaillard, and I. Kelman. 2012. Framing disaster: theories and stories seeking to understand hazards, vulnerability and risk. Pages in B. Wisner, J. C. Gaillard, and I. Kelman, editors. Handbook of hazards and disaster risk reduction. Routledge, New York, New York, USA.

Wright, D. J., S. H. Bloomer, C. J. MacLeod, B. Taylor, and A. M. Goodliffe. 2000. Bathymetry of the Tonga Trench and Forearc: a map series. Marine Geophysical Researches 21(5):489-512. http:// dx.doi.org/10.1023/A:1026514914220

Yin, R. K. 2009. Case study research: design and methods. Sage, Thousand Oaks, California, USA. 